\title{
TAXONOMIC REVISION OF GEESINKORCHIS (COELOGYNINAE; EPIDENDROIDEAE; ORCHIDACEAE)
}

\author{
SHIH-CHUNG HSU ${ }^{1,2}$, BARBARA GRAVENDEEL ${ }^{1} \&$ ED F. DE VOGEL ${ }^{1}$
}

\begin{abstract}
SUMMARY
An updated taxonomic description of the orchid genus Geesinkorchis and a new identification key are given in addition to a distribution map, photographs and analytical drawings. Two new species ( $G$. quadricarinata and G. breviunguiculata) are described from Borneo and Sumatra, respectively.
\end{abstract}

Key words: Coelogyninae, Geesinkorchis, Orchidaceae, Borneo, Sumatra, taxonomy.

\section{INTRODUCTION}

The orchid genus Geesinkorchis de Vogel (Coelogyninae; Epidendroideae) was first described in 1984 by De Vogel to commemorate the late botanist Rob Geesink. According to De Vogel (1984), the characters distinguishing Geesinkorchis from other genera in the Coelogyninae are the successively flowering inflorescences in combination with small flowers, floral bracts caducous at anthesis, few sterile bracts, and the presence of a minute, thin stipe. The latter structure was recently identified as a caudicle rather than a stipe (Hsu et al., unpubl. data). Although caudicles are common in other Coelogyninae, phylogenetic studies of the subtribe so far (Gravendeel, 2000; Gravendeel et al., 2001; Gravendeel et al., 2005) indicate that Geesinkorchis can be considered a separate genus, nonetheless.

In all publications on Geesinkorchis to date, only two species from Borneo are mentioned (De Vogel, 1986; Beaman et al., 2001; Wood, 2003). In the past decade, plant material was collected in Indonesia and Malaysia that did not match the existing descriptions (Beaman et al., 2001) and two new species of Geesinkorchis are published here together with an updated generic description.

\section{TAXONOMIC TREATMENT}

\section{GEESINKORCHIS}

Geesinkorchis de Vogel (1984) 199-201; (1986) 43-44; T.E. Beaman et al. (2001) 324; J.J. Wood \& P.J. Cribb (1994) 197. - Type species: Geesinkorchis alaticallosa de Vogel.

1) Nationaal Herbarium Nederland, Universiteit Leiden branch, P.O. Box 9514, 2300 RA Leiden, The Netherlands; e-mail corresponding author: gravendeel@nhn.leidenuniv.nl.

2) Current address: Herbarium, Research Centre for Biodiversity, Academia Sinica, Taipei 115, Taiwan; e-mail: bohsu@gate.sinica.edu.tw. 
Epiphytes (sometimes also terrestrial or lithophytic). Roots sparsely branched, puberulous. Rhizome creeping, sometimes branched. Pseudobulbs close together, elliptic or narrowly ovoid, flattened, with two to several longitudinal ridges. Scales of the young shoot triangular, imbricate, distichous, papyraceous to thin pergamentaceous, soon dry but long persistent, finally disintegrating into fine fibres, nerves many, apex acute. Leaves two per pseudobulb, petiolate; petioles deeply channelled; blade narrowly (ob)ovate, subcoriaceous to coriaceous, more or less stiff, main nerves prominent, other nerves much less so to rather indistinct, apex acute. Inflorescence terminal, erect, rigid, starting proteranthous, continuing to produce flowers in succession until long after the pseudobulb and leaves are fully developed. Peduncle erect, consisting of one internode, not elongating after anthesis, long, sturdy. Rachis elongating during anthesis, straight to zigzag; internodes short. Sterile bracts at base of the rachis absent or few, caducous at anthesis. Floral bracts entirely covering the young floral buds, closely imbricate, distichous, pergamentaceous to papyraceous, caducous at anthesis, triangular, with several groups of minute, stellately arranged uniseriate hairs inside, folded along the midrib; nerves many, fine, apex acute. Flowers up to 150, opening in succession from the base upwards, one or two open at the same time, widely opening; lip mostly turned downward. Pedicel curved, terete to more or less angular. Ovary more or less angular with 3 rather prominent ribs. Median sepal deeply concave, ovate, hairy inside just like the floral bracts; midrib prominent; apex acute. Lateral sepals oblique, ovate to ovate-elliptic, hairy inside just like the floral bracts, concave in the basal half, midrib usually prominent and keel-like, apex acute. Petals linear, sometimes oblique, curved or slightly rolled backwards, nerves 3, apex rounded to truncate. Lip pandurate when flattened. Hypochilium base saccate, hairy or glabrous, with or without keels, lateral lobes triangular or spatulate, often oblique, apex curved upward or erect or curved downward. Callus starting from or beyond the hypochilium base, ending on the claw or at the base of the epichilium, consisting of two or four lateral keels, usually curved inward, and sometimes also a central erect ridge. Epichilium spatulate, distinctly or indistinctly clawed; blade usually channelled, erect along the midvein or more or less flat; margin irregular, apex acute, broadly rounded, or retuse and 2-lobed when flattened. Column hood-like, curved or straight in lateral view, base with or without a swollen transverse ridge, apex acute to broadly acute or truncate when flattened, with lateral lobes or teeth, margin irregular. Anther oblong-ovate to broadly ovate-triangular in outline, erect or incumbent, base cordate, apex acute to acuminate, recurved or straight. Pollinarium consisting of a caudicle bearing 4 pollinia. Caudicle elastic when fresh, with or without lateral lobes attached to the base of each pair of pollinia and always with a minute, elastic band attached to the centre of each pollinium. Pollinia obliquely elliptic, with a shallow depression where connected to the caudicle. Stigma cup-shaped, ovate to triangular in outline, rostellum bifid, not clearly separated from the stigma. Capsule ellipsoid; ribs 6, juga 3, flat and band-like, valvae 3, entire, in the centre elevated in longitudinal keels; perianth fragments and the column persistent on the apex. Seeds small, many, fusiform.

Distribution - Borneo (three species) and Sumatra including Mentawi Islands (one species). See Map 1. 




Map 1. Distribution of Geesinkorchis alaticallosa de Vogel (๑), G. phaiostele (Ridl.) de Vogel (ロ), G. quadricarinata Shih C. Hsu, Gravend. \& de Vogel ( $\mathbf{\Delta})$ and G. breviunguiculata Shih C. Hsu, Gravend. \& de Vogel $(\boldsymbol{\nabla})$.

Habitat \& Ecology - Epiphytes, sometimes growing on the ground or on rocks, in montane forest or kerangas vegetations on podsolic soils in the shade to full sun, between 400-2000 $\mathrm{m}$ above sea level.

Conservation status - Geesinkorchis quadricarinata and G. breviunguiculata are known from few collections only and must be considered rare. Geesinkorchis alaticallosa and G. phaiostele are locally common in Brunei, Sarawak, Sabah, and Kalimantan, but suitable habitats are rapidly decreasing.

Artificial hybrids - None registered.

\section{KEY TO THE SPECIES}

1a. Callus on the lip with a central erect ridge. Column base without a swollen transverse ridge $\ldots \ldots \ldots \ldots \ldots \ldots \ldots \ldots \ldots \ldots \ldots \ldots \ldots \ldots \ldots \ldots$. G. alaticallosa

b. Callus on the lip without a central erect ridge. Column base with a swollen trans-

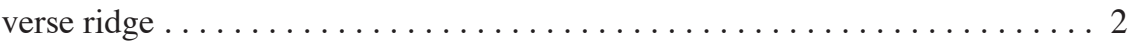

2a. Epichilium apex deeply retuse when flattened. Anther incumbent. Column hood with two incurved lateral lobes with rounded apex ....... 2. G. phaiostele

b. Epichilium apex rounded to acute when flattened. Anther not incumbent. Column hood with two flattened lateral teeth with acute apex ........... 3

3a. Epichilium $5.3-5.7$ by $7.2-8 \mathrm{~mm}$, broadly triangular-ovate, apex acute; claw 1.9-2.1 mm long. Callus with four keels, two longer ones on the hypochilium, two shorter ones on the claw $\ldots \ldots \ldots \ldots \ldots \ldots \ldots$. G. quadricarinata

b. Epichilium 3.3-4.1 by $3.8-4.2 \mathrm{~mm}$, suborbicular, apex rounded; claw $0.3-0.6 \mathrm{~mm}$ long. Callus with two keels 




Fig. 1. Geesinkorchis alaticallosa de Vogel. a. Habit; b. floral bract; c. flower, frontal view; d. flower, side view; e. dorsal sepal, petal, lateral sepal, and lip; f. flower with sepals and petals removed, side view; g. lip, side view; h; column; i. anther; j. pollinia; k; seed (a-e: Leiden cult. 30182; f-k: Geesink 8965). Drawings Jaap Jan Vermeulen and Barbara Gravendeel. 


\section{Geesinkorchis alaticallosa de Vogel - Fig. 1, Plate 1a}

Geesinkorchis alaticallosa de Vogel (1984) 201; (1986) 44; T.E. Beaman et al. (2001) 324; J.J. Wood \& P.J. Cribb (1994) 197. - Type: Geesink 8965 (holo L; iso BO), Indonesia, Borneo.

Plant 50-80 cm high. Roots up to $25 \mathrm{~cm}$ long, 1-3.5 $\mathrm{mm}$ diameter. Pseudobulbs ovate-elliptic, rather sturdy, (5-)7.5-9.5(-12) cm long. Scales of the young shoot 4-10, smallest one $1.5-3.5 \mathrm{~cm}$ long, longest one 5-8 cm long, nerves 60-80. Petiole $3-10 \mathrm{~cm}$ by $2-4 \mathrm{~mm}$. Leaf blade $16-32$ by $2.5-5 \mathrm{~cm}$, main nerves $3-7$. Inflorescence producing up to 75 flowers. Peduncle $27-43 \mathrm{~cm}$ long, 3-4 $\mathrm{mm}$ diameter. Rachis $17-27 \mathrm{~cm}$ long, internodes $3-6 \mathrm{~mm}$ long. Floral bracts $13-15.5$ by $9-11.5 \mathrm{~mm}$ when flattened, nerves 27-34. Pedicel $0.5-0.8 \mathrm{~mm}$ diameter. Ovary $1.2-1.6 \mathrm{~mm}$ diameter. Median sepal 7-8 by 3.5-4 mm, nerves 7-9. Lateral sepals obliquely ovate-oblong, $7-10$ by $2.5-4 \mathrm{~mm}$, nerves $5-7$. Petals curved backward in apical third, 7.7-9 by c. $1 \mathrm{~mm}$. Lip 7-9 mm long when flattened. Hypochilium 3.2-4 mm long, base 1-1.2 by $2-3.1 \mathrm{~mm}, 1-1.4 \mathrm{~mm}$ deep, with simple hairs inside, without keels, lateral lobes more or less triangular, $1.5-2$ by $1.5-2 \mathrm{~mm}$, width over the lateral lobes $5.5-6.5 \mathrm{~mm}$, margin glabrous, apex rounded, curved downwards. Callus consisting of a keeled, elevated ridge, in lateral view oblique semi-ovate, in front shallowly grooved, starting from the hypochilium base and extending up to halfway onto the claw, 4-4.5 by $1.6-1.9 \mathrm{~mm}$; keels 2 , running from the base of the callus to halfway the hypochilium, in front gradually lowering, 3.5-3.8 $\mathrm{mm}$ long, $0.5-1 \mathrm{~mm}$ high; ridge abruptly ascending at the basal third of the callus, abruptly descending at the middle of the callus while dividing into two keels reaching up to halfway the claw, 2.7-3 mm long, 1-1.5 $\mathrm{mm}$ high, 0.3-0.4 mm thick, apex glabrous. Epichilium broadly and shortly spatulate when flattened, 3.6-6.1 mm long, widest part 3-6 mm wide, claw $1.1-1.9$ by $2-3.4 \mathrm{~mm}$, its margin covered by minute warts, blade when flattened $2.5-4.2$ by $3-6 \mathrm{~mm}$, medially channelled, laterally somewhat convex, margin slightly irregular, apex rounded to broadly acute. Column straight in lateral view, $3.8-4.6$ by $2.2-3 \mathrm{~mm}, 2-3.4 \mathrm{~mm}$ deep, base without a swollen transverse ridge; column hood not lobed, margin more or less entire, curved inward, apex truncate. Anther oblong-ovate in outline, 1.9-2.3 by $1.3-1.5 \mathrm{~mm}$, not incumbent, apex acute, straight. Pollinia $0.6-0.8$ by $0.35-0.5 \mathrm{~mm}$. Caudicle $1.3-1.8$ by $0.3-0.4 \mathrm{~mm}$, with two oblong lateral lobes connected to the base of the pollinia, $0.25-0.35$ by c. $0.1 \mathrm{~mm}$. Stigma including rostellum ovate in outline, $2.3-2.7$ by $1.5-1.8 \mathrm{~mm}$; rostellum triangular, apex acute. Capsule $16-20$ by $8-11$ $\mathrm{mm}$. Seeds $0.5-1$ by $0.2-0.3 \mathrm{~mm}$.

Distribution - Borneo: Brunei, Kalimantan, Sabah, Sarawak.

Altitude - 400-1000 m.

Notes -1 . The epithet alaticallosa (which is Latin for with a winged callus) refers to the central erect ridge on the callus which is ornamented with two keels.

2. Pedicel and ovary apple green; sepals and petals light yellow; lip white or light yellow, tinged reddish brown; callus white, tinged reddish brown; column chocolate brown to dark maroon; anther rusty brown. Sweet smell.

3. This species can easily be recognized by the central erect ridge of the callus of the hypochilium. 


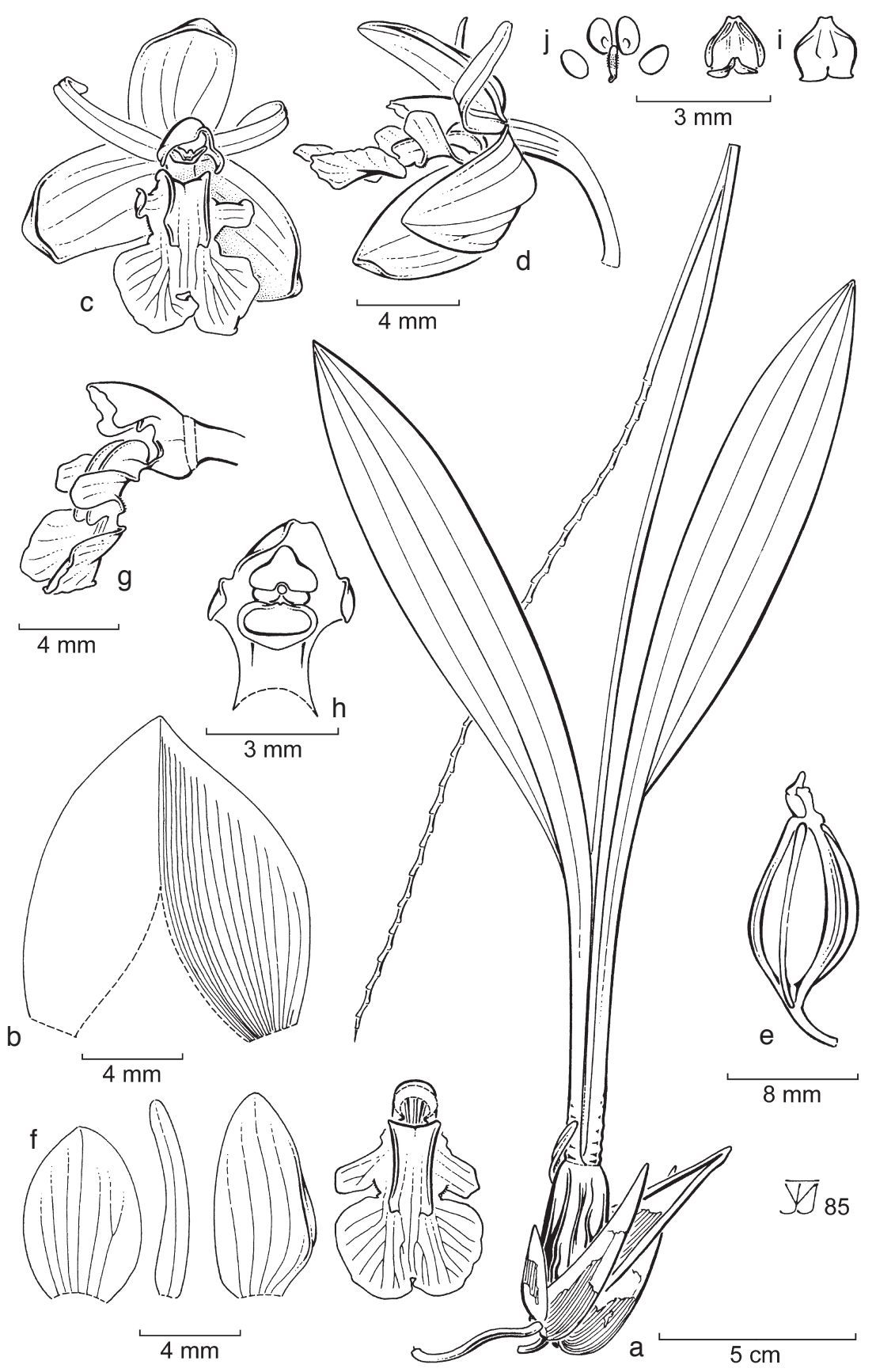

Fig. 2. Geesinkorchis phaiostele (Ridl.) de Vogel. a. Habit; b. floral bract; c. flower, frontal view; d. flower, side view; e. capsule; f. dorsal sepal, petal, lateral sepal, and lip; g. flower with sepals and petals removed, side view; h. column; i. anther; j. pollinia (all: Leiden cult. 22090). Drawing Jaap Jan Vermeulen. 


\section{Geesinkorchis phaiostele (Ridl.) de Vogel — Fig. 2, Plate 1b}

Geesinkorchis phaiostele (Ridl.) de Vogel (1984) 198; (1986) 45; T.E. Beaman et al. (2001) 324; J.J. Wood \& P.J. Cribb (1994) 199. — Coelogyne phaiostele Ridl. (1910) 51. — Lectotype: Lewis s.n. (K), Malaysia, Borneo, June 1909.

Coelogyne ridleyana Schltr. (1910) 561. - Type: Brooks 14 (holo BM; iso K), Malaysia, Borneo.

Pholidota triloba J.J. Sm. (1931) 105. - Type: Clemens \& Clemens 20398 (holo L; iso NY), Indonesia, Borneo.

Plant 25-60 cm high. Roots up to $25 \mathrm{~cm}$ long, 1-3 mm diameter. Pseudobulbs ellipticoblong, very slender to short and thick, 3-8(-24) cm long. Scales of the young shoot 5-11, smallest one $0.5-1 \mathrm{~cm}$ long, longest one 6.5-12.5 cm long, nerves 45-80. Petiole $3-17.5 \mathrm{~cm}$ by $2-4 \mathrm{~mm}$. Leaf blade $6.5-30$ by $1.3-4.2 \mathrm{~cm}$, main nerves $3-5$. Inflorescence producing 50 to over 100 flowers. Peduncle $8-33 \mathrm{~cm}$ long, $1.5-3 \mathrm{~mm}$ diameter. Rachis $20-35 \mathrm{~cm}$ long, internodes $3-5 \mathrm{~mm}$ long. Floral bracts $12-17$ by 8-13 mm when flattened, nerves 30-47. Pedicel $0.3-0.5 \mathrm{~mm}$ diameter. Ovary $0.7-1.2$ $\mathrm{mm}$ diameter. Median sepal $5.5-8.4$ by $3-5 \mathrm{~mm}$, nerves $5-7$. Lateral sepals obliquely ovate to ovate-elliptic, $5.2-10$ by $2.3-5.2 \mathrm{~mm}$, nerves 5 or 6 . Petals rather strongly curved backward in apical third, $5-8$ by $0.5-1.5 \mathrm{~mm}$. Lip $4.5-10 \mathrm{~mm}$ long when flattened. Hypochilium 3-4 mm long, base 1-2 by 1-1.6 $\mathrm{mm}, 1-1.5 \mathrm{~mm}$ deep, glabrous, with or without 3 short keels, lateral lobes (obliquely) spatulate, $0.5-2.3$ by $0.5-1.2$ $\mathrm{mm}$, width over the lateral lobes $2-7 \mathrm{~mm}$, margin near the claw with many minute warts, apex rounded to truncate, curved upwards. Callus consisting of two keels but without an erect central ridge, starting beyond the hypochilium base and ending at the base of the epichilium, $4-5.4$ by $2-2.3 \mathrm{~mm}$, keels running along the whole length of the callus, 3-4 mm long, 0.7-1 mm high, apex covered by minute warts. Epichilium broadly ovate when flattened, 3-4.9 mm long, widest part 5-6 mm wide, its margin covered by minute warts, claw $0.8-1.1$ by $1.8-3 \mathrm{~mm}$, covered by many minute warts, blade when flattened $2.7-4$ by $4-5 \mathrm{~mm}$, median channelled, curved downward at apical half part, margin irregular, wavy, apex retuse, lobules often curved upward, slightly overlapping. Column straight in lateral view, $3-4.5$ by $2.3-3 \mathrm{~mm}, 2-2.5 \mathrm{~mm}$ deep, base with a swollen transverse ridge; column hood 3-lobed, median lobe with broadly rounded apex, margin slightly irregular serrate, lateral lobes elliptic, curved inward, apex rounded. Anther broadly ovate-triangular in outline, $1-1.2$ by $1-1.2 \mathrm{~mm}$, incumbent, apex acute, truncate when flattened, folded along the midvein and recurved. Pollinia $0.5-0.7$ by $0.3-0.4 \mathrm{~mm}$. Caudicle $0.6-0.75$ by c. $0.2 \mathrm{~mm}$, minutely branched at the apex where connected to the pollinia. Stigma including rostellum ovate in outline, $0.8-1.5$ by $1-1.5 \mathrm{~mm}$; rostellum broadly triangular, apex acute. Capsule c. 12 by c. 7.5 $\mathrm{mm}$. Seeds up to $1 \mathrm{~mm}$ long.

Distribution - Borneo: Kalimantan, Sarawak.

Altitude - 750-2000 m.

Notes -1 . The epithet phaiostele (which is Latin for dark column) refers to the maroon column.

2. Pedicel and ovary pink; sepals and petals light yellow; lip white, with small central brownish tinged patch; callus white; column light brown to very dark maroon; anther orange brown. Sweet smell.

3. This species can easily be recognized by the retuse apex of the epichilium and column hood with incurved lateral lobes with rounded apex. 

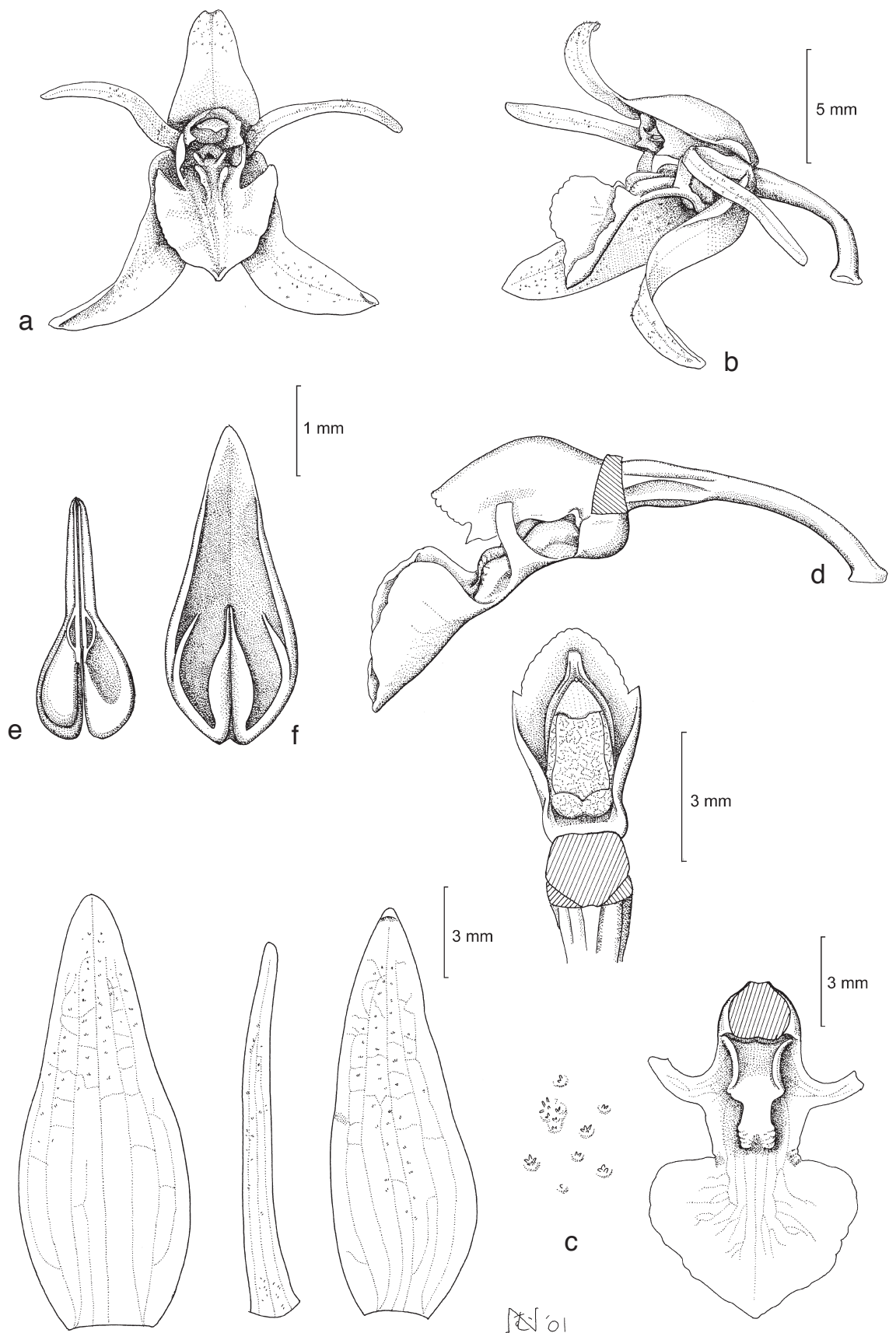

Fig. 3. Geesinkorchis quadricarinata Shih C. Hsu, Gravend. \& de Vogel. a. Flower, frontal view; b. flower, side view; c. dorsal sepal, petal, lateral sepal with magnification of hairs inside, and lip; d. flower with sepals and petals removed, side view; e. pollinia; f. anther (all: Leiden cult. 914139). Drawing Mutsuko Nakajima. 
3. Geesinkorchis quadricarinata Shih C. Hsu, Gravend. \& de Vogel, spec. nov. Fig. 3, Plate 1c

Labelli callus carinis lateralibus quatuor, duabus longioribus in hypochilio, brevioribus in ungue. Epichilium late triangulare ovatum apice acuto. - Typus: Leiden cult. 914139 (de Vogel) (holo L), Malaysia, Borneo, Sarawak, Hose Mountains.

Sterile parts not seen. Inflorescence not seen. Floral bracts $18-22$ by $9.5-12.5 \mathrm{~mm}$ when flattened, nerves 28-35. Pedicel $0.75-0.9 \mathrm{~mm}$ diameter. Ovary 1.4-1.6 mm diameter. Median sepal $12-13.5$ by $4.9-5.2 \mathrm{~mm}$, nerves 7 . Lateral sepals slightly oblique-ovate, $12-13$ by $3.7-4.3 \mathrm{~mm}$, nerves $5-7$. Petals curved backward, $11.5-12.2$ by $0.9-1 \mathrm{~mm}$. Lip $10.5-11 \mathrm{~mm}$ long when flattened. Hypochilium $3.5-4 \mathrm{~mm}$ long, base $0.7-0.9$ by $2.3-2.7 \mathrm{~mm}, 0.5-0.7 \mathrm{~mm}$ deep, glabrous, without keels, lateral lobes spatulate, $2.3-2.6$ by $0.7-0.8 \mathrm{~mm}$, width over the lateral lobes $7.4-7.8 \mathrm{~mm}$, margin glabrous, apex rounded to truncate, curved backwards. Callus consisting of four lateral keels but without an elevated central ridge, starting from the hypochilium base and ending at the base of the epichilium, $4.6-4.9$ by $1.35-1.55 \mathrm{~mm}$, two basal lateral keels starting beyond the base of the callus and ending at the apex of the hypochilium, sometimes slightly extending onto the claw, 2.5-2.7 $\mathrm{mm}$ long, $0.5-0.7 \mathrm{~mm}$ high, two frontal lateral keels semi-elliptic in lateral view, starting at more or less the middle of the claw and ending at the apex of the claw, sometimes extending onto the epichilium, 0.8-1.1 mm long, 0.4-0.5 mm high, apex glabrous. Epichilium broadly ovate when flattened, 5.3-5.7 mm long, widest part 7.2-8 mm wide; claw $1.9-2.1$ by $2.9-3.3 \mathrm{~mm}$, glabrous, blade when flattened $5-5.5$ by $7.5-8 \mathrm{~mm}$, folded along the midvein, margins slightly irregular, apex acute to rounded. Column more or less curved in lateral view, $5-5.45$ by $3.2-3.6 \mathrm{~mm}, 2.6-2.75 \mathrm{~mm}$ deep, base usually with a swollen transverse ridge; column hood not lobed, margin irregular, lateral sides with two small triangular teeth with acute apex, apex broadly acute. Anther oblong-ovate in outline, 3.4-3.7 by $1.5-1.7 \mathrm{~mm}$, not incumbent, apex acuminate, straight. Pollinia $0.9-1.1$ by $0.48-0.6 \mathrm{~mm}$. Caudicle $1.8-2$ by $0.3-0.4 \mathrm{~mm}$, with two elliptic lateral lobes connected to the base of the pollinia. Stigma including rostellum more or less triangular in outline, 3.4-3.8 by $1.6-1.8 \mathrm{~mm}$; rostellum triangular, apex acute. Capsule not seen.

Distribution - Borneo: Sarawak (Bahagian Kapit).

Altitude - 800-1000 m.

Notes -1 . The epithet quadricarinata (which is Latin for four-keeled) refers to the number of keels of the callus on the lip.

2. Pedicel and ovary green; sepals and petals brownish ochre; lip yellowish cream, with two brown lines bordering the front of the raised median band with the keels; column hood dark brown, stigma ochreous. Smell not recorded.

3. This species can easily be recognized by the four keels of the callus; two on the hypochilium and two on the claw, and the broadly triangular-ovate apex of the epichilium. 



Fig. 4. Geesinkorchis breviunguiculata Shih C. Hsu, Gravend. \& de Vogel. a. Habit; b. flower, frontal view; c. flower, side view; d. dorsal sepal, petal, lateral sepal with magnification of hairs inside, and lip; e. flower with sepals and petals removed, side view; f. column; g. anther; h. pollinia (all: Leiden cult. 20010030). Drawing Mutsuko Nakajima. 
4. Geesinkorchis breviunguiculata Shih C. Hsu, Gravend. \& de Vogel, spec. nov. Fig. 4, Plate 1d

Labelli callus carinis lateralibus duabus. Epichilium suborbiculare apice rotundato. Typus: Leiden cult. 20010030 (Wubben) (holo L), Indonesia, Sumatra, Siberut.

Plant 25-40 cm high. Roots up to $4.5 \mathrm{~cm}$ long, 2-2.5 $\mathrm{mm}$ diameter. Pseudobulbs narrowly ovoid, sturdy, 4.5-5 cm long. Scales of the young shoot 3-6, smallest one $2-2.5 \mathrm{~cm}$ long, longest one $3.5-4 \mathrm{~cm}$ long, nerves $40-60$. Petiole $2.8-6 \mathrm{~cm}$ by $1.5-2$ $\mathrm{mm}$. Leaf blade $9-14$ by $1.4-2.2 \mathrm{~cm}$, main nerves $4-7$. Inflorescence producing up to 150 flowers. Peduncle $6.5-35 \mathrm{~cm}$ long, 1.5-2 mm diameter. Rachis 8-17 cm long, internodes 1-4 mm long. Floral bracts $11-12$ by $8-10 \mathrm{~mm}$ when flattened, nerves 30-34. Pedicel 0.4-0.5 mm diameter. Ovary 0.8-1.1 mm diameter. Median sepal $7-7.4$ by $3.6-4 \mathrm{~mm}$, nerves 7 . Lateral sepals obliquely ovate-oblong, $7.3-7.7$ by $3.4-3.7 \mathrm{~mm}$, nerves 5. Petals usually curved backward at apical third part, $6.8-7$ by 0.7-0.9 mm. Lip 6.6-7 mm long when flattened. Hypochilium 2.4-2.7 mm long, base $0.7-0.8$ by $1.9-2.2 \mathrm{~mm}$, c. $0.7 \mathrm{~mm}$ deep, glabrous, without keels, lateral lobes deltoid to obliquely deltoid, $0.4-0.6$ by $0.4-0.5 \mathrm{~mm}$, width over the lateral lobes $3.4-3.8 \mathrm{~mm}$, margin glabrous, apex rounded, sometimes turned downwards. Callus consisting of two lateral keels but without an elevated central ridge, starting beyond the hypochilium base and ending at the basal portion of the epichilium, 2.6-3 by $1.5-1.9 \mathrm{~mm}$, keels running along the whole length of the callus, in front gradually lowering, 0.7-0.9 mm high at the base, 3-4 mm high in front, apex glabrous. Epichilium suborbicular when flattened, $3.3-4.1 \mathrm{~mm}$ long, widest part $3.8-4.2 \mathrm{~mm}$ wide, claw $0.3-0.6$ by $2.7-3 \mathrm{~mm}$, glabrous, marginal half portion concave, blade when flattened $3.5-4$ by $3.7-4.2 \mathrm{~mm}$, median slightly channelled, margin slightly irregular, apex broadly rounded. Column curved in lateral view, $3.8-4.6$ by $2.8-3.1 \mathrm{~mm}, 1.9-2.3 \mathrm{~mm}$ deep, base with a swollen transverse ridge; column hood not lobed, margin irregular with 4-6 teeth, lateral sides with a small triangular tooth, apex (broadly) acute. Anther oblong-ovate in outline, $2.2-2.3$ by c. $1.4 \mathrm{~mm}$, not incumbent, apex acuminate to rounded to truncate, slightly contracted above the anther, straight. Pollinia $0.7-0.74$ by $0.43-0.52 \mathrm{~mm}$. Caudicle $1.5-1.55$ by $0.3-0.35 \mathrm{~mm}$, with two oblong lateral lobes connected to the base of the pollinia. Stigma including rostellum broadly ovate in outline, 1.1-1.6 by $1.1-1.5 \mathrm{~mm}$; rostellum broadly triangular, apex acute. Capsule not seen.

Distribution - North Sumatra and Siberut.

Altitude - Circa $200 \mathrm{~m}$.

Notes -1 . The epithet breviunguiculata (which is Latin for shortly clawed) refers to the short claw of the lip.

2. Pedicel and ovary green; sepals and petals ochre yellow; lip light yellow, faintly orange-brown at the base; margins of the midlobe white; keels white at the base of the lip, in front with light brown edge. Smell not recorded.

3. This species can easily be recognized by the suborbicular and indistinctly clawed epichilium. 


\section{ACKNOWLEDGEMENTS}

We thank the directors and curators of the herbaria of The Royal Botanic Gardens Kew, Nationaal Herbarium Nederland - Universiteit Leiden branch, the Natural History Museum in London and Singapore Botanic Gardens for the loan of dried and spirit specimens. Mutsuko Nakajima, Jaap Jan Vermeulen and Ben Kieft and Jan Frits Veldkamp are thanked for their help with the drawings and Latin description of the new species, respectively. Koos Wubben and Art Vogel kindly provided fresh plant material. The Alberta Mennega Stichting financed travel expenses of the first author.

\section{REFERENCES}

Beaman, T.E., J.J. Wood, R.S. Beaman \& J.H. Beaman. 2001. Orchids of Sarawak. Kota Kinabalu, Sabah: Natural History Publications (Borneo) in association with The Royal Botanic Gardens, Kew.

De Vogel, E.F. 1984. Precursor to a revision of the genera Entomophobia (gen. nov.), Geesinkorchis (gen. nov.), Nabaluia and Chelonistele (Orchidaceae-Coelogyninae). Blumea 30: 197-205.

De Vogel, E.F. 1986. Revisions in Coelogyninae (Orchidaceae) II. The genera Bracisepalum, Chelonistele, Entomophobia, Geesinkorchis and Nabaluia. Orchid Monogr. 1: 17-51.

Gravendeel, B. 2000. Reorganising the orchid genus Coelogyne - a phylogenetic classification based on molecules and morphology. PhD thesis Universiteit Leiden. Nationaal Herbarium Nederland, Leiden, The Netherlands.

Gravendeel, B., M.W. Chase, E.F. de Vogel, M.C. Roos, T.H.M. Mes \& K. Bachmann. 2001. Molecular phylogeny of Coelogyne (Epidendroideae; Orchidaceae) based on plastid RFLPs, matK, and nuclear ribosomal ITS sequences: evidence for polyphyly. Amer. J. Bot. 88, 10: 1915-1927.

Gravendeel, B., A. Schuiteman \& E.F. de Vogel. 2005. Coelogyninae. In: A.M. Pridgeon, P.J. Cribb, M.W. Chase \& F.N. Rasmussen (eds.), Genera Orchidacearum Vol. 4, Epidendroideae (Part 1): 29-88. Oxford University Press, New York.

Ridley, H.N. 1910. Coelogyne phaiostele Ridl. J. Straits Branch Roy. Asiat. Soc. 54: 51.

Schlechter, R. 1910. Coelogyne ridleyana Schltr. Feddes Repert. Spec. Nov. Regni Veg. Beih. 8: 561.

Smith, J.J. 1931. Pholidota triloba J.J. Sm. Brittonia 1: 105.

Wood, J.J. 2003. Orchids of Borneo Vol. 4. Kota Kinabalu, Sabah: Natural History Publications (Borneo) in association with The Royal Botanic Gardens, Kew.

Wood, J.J. \& P.J. Cribb. 1994. A check-list of the orchids of Borneo. Royal Botanic Gardens, Kew. London, United Kingdom.

\section{IDENTIFICATION LIST}

Dates are used if the number of the collection is unknown.

1. = G. alaticallosa $; \quad 2 .=$ G. phaiostele $; \quad 3 .=$ G. quadricarinata $; \quad 4 .=$ G. breviunguiculata

Afriastini 2719: 4 - Anderson 175: 2; 225: 2.

Beaman 11575: 2; 11882: 2 - Boden Kloss 12290: 4 - Brooks 14: 2.

Chan s.n. (April 2000): 1 - Clemens \& Clemens 20398: 1 - Cribb 89/68: 1.

De Vogel 9370: 3; 8227: 1.

Geesink 8965: 1.

Hewitt 12: 2.

Kostermans 14016: 1.

Lamb 224/85: 1; 351/85: 1 - Leiden cult. 22090: 2; 30182: 1; 30700: 2; 914139 (de Vogel): 3;

914307: 3; 970467: 1; 20010030 (Wubben): 4 - Lewis s.n. (June 1909): 2.

Mogea 3847: 1 .

Dwi Murti Puspitaningtyas s.n. (photograph): 4.

S series (Martin) 37582: 2; (Awa et al.) 50465: 1; (Mohtar \& Yii) 66149: 1.

Vermeulen \& Lamb 313: 1 .

Wood 751: 1. 

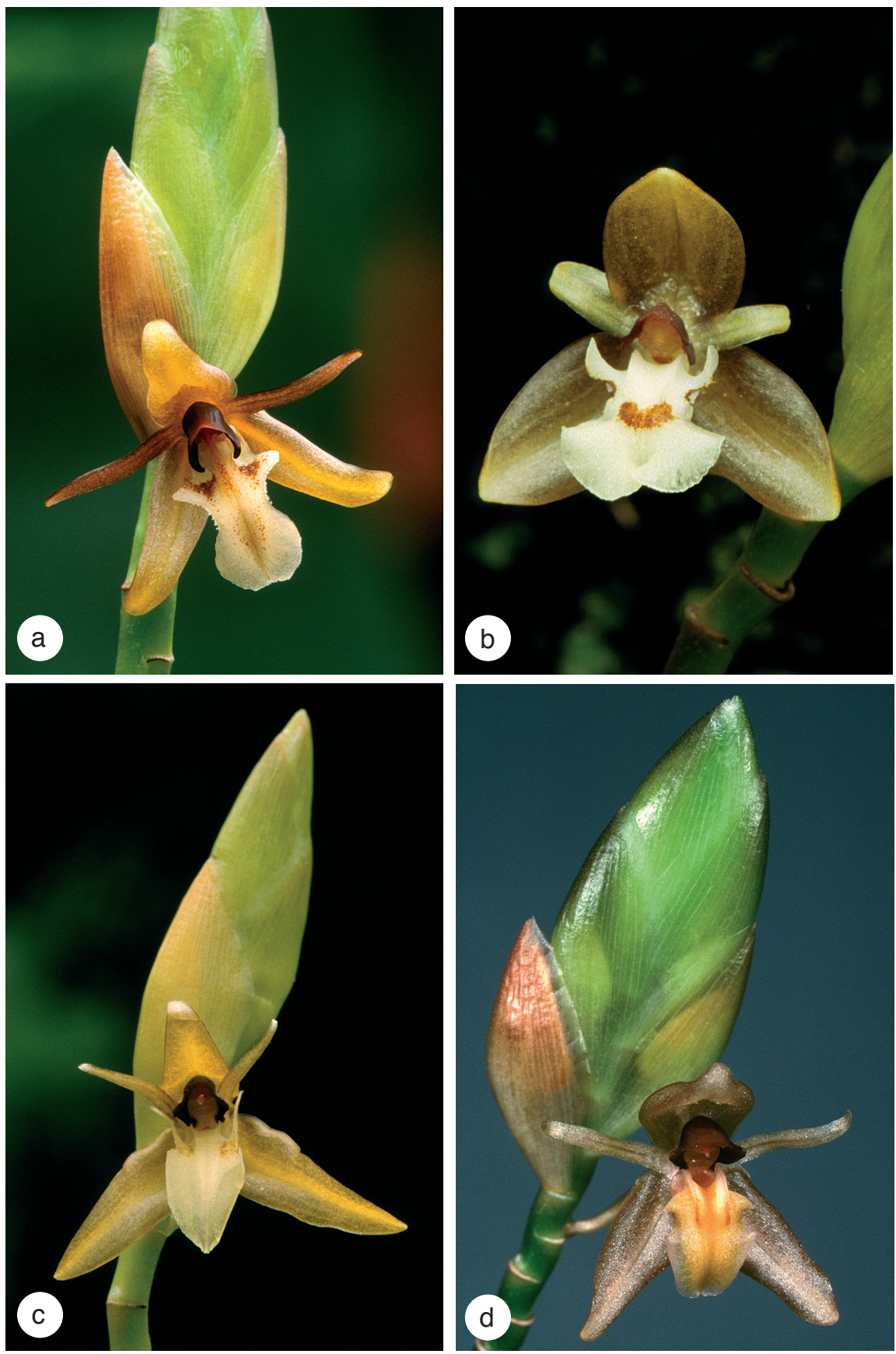

Plate 1. a. Geesinkorchis alaticallosa de Vogel (photograph J. Meijvogel); b. G. phaiostele (Ridl.) de Vogel (photograph Shih-Chung Hsu); c. G. quadricarinata Shih C. Hsu, Gravend. \& de Vogel (photograph J. Meijvogel); d. G. breviunguiculata Shih C. Hsu, Gravend. \& de Vogel (photograph L.Y.Th. Westra). 